\title{
ANALISIS PENGARUH PENGANGGURAN TERHADAP TINGKAT KEMISKINAN DI INDONESIA DALAM PERSPEKTIF EKONOMI ISLAM
}

\author{
Siti Masrofah
}

Sekolah Tinggi Ekonomi Islam SEBI

\begin{abstract}
The problem of poverty is not only a problem for developing countries such as Indonesia, spacious more this problem is the focus of many countries in the world. Efforts to decrease poverty are as important as decrease unemployment too. Even though Indonesia has succeeded in decreasing poverty, in reality, there are still many Indonesians, especially the provinces in Eastern Indonesia (KTI) who are still on the poverty line. In a Sharia economic perspective, unemployment is the cause of poverty, the higher the unemployment, the greater the opportunity for individuals to be unable to comply with their needs, so the more unemployed, the more people are on the poverty.
\end{abstract}

Keywords : Poverty, Unemployment, Sharia economic.

\begin{abstract}
Abstrak
Permasalahan kemiskinan tidak hanya menjadi masalah bagi negara sedang berkembang seperti Indonesia, lebih luas lagi permasalahan ini menjadi fokus banyak negara di dunia. Upaya menurunkan tingkat kemiskinan sama pentingnya dengan mengurangi angka pengangguran. Walaupun Indonesia berhasil menurunkan angka kemiskinan namun pada realitanya masih banyak masyarakat Indonesia utamanya provinsi-provinsi pada Kawasan Timur Indonesia (KTI) yang masih berada dalam garis kemiskinan. Dalam perspektif ekonomi Syariah, pengangguran merupakan penyebab kemiskinan, semakin tinggi pengangguran maka peluang individu tidak dapat memenuhi kebutuhannya semakin besar, sehingga semakin banyak penduduk yang menganggur maka semakin banyak juga penduduk yang berada dalam garis kemiskinan.
\end{abstract}

Kata kunci: Kemiskinan, Pengangguran, Ekonomi Syariah.

\section{Pendahuluan}

Pembangunan ekonomi adalah proses meningkatnya jumlah produksi suatu negara yang ditandai dengan adanya peningkatan pendapatan perkapita penduduk suatu masyarakat. Pembangunan ekonomi di Indonesia diharapkan mampu mewujudkan keadilan, berdaya saing, maju, dan sejahtera pada masyarakat (Saputra,2011; Lestari,2017). Menurut Kalsum instrument pembangunan ekonomi 
bertujuan untuk meningkatkan taraf hidup masyarakat, memperluas kesempatan kerja dan mengarahkan pembagian penadapatan secara merata. Perluasan kesempatan kerja merupakan upaya pemerintah untuk mengurangi jumlah penggangguran serta menekan laju tingkat kemiskinan. Kemiskinan dan kesenjangan dalam distribusi pemerataan pendapatan merupakan dua masalah besar yang banyak terjadi di negara sedang berkembang(NSB), tidak terkecuali pada Indonesia (Lestari, 2017).

Berikut disajikan presentase kemiskinan di Indonesia dalam periode 2015-2019 adalah sebagai berikut:

\section{Gambar 1 \\ Tingkat Kemiskinan di Indonesia \\ Tahun 2015-2019 (persen)}

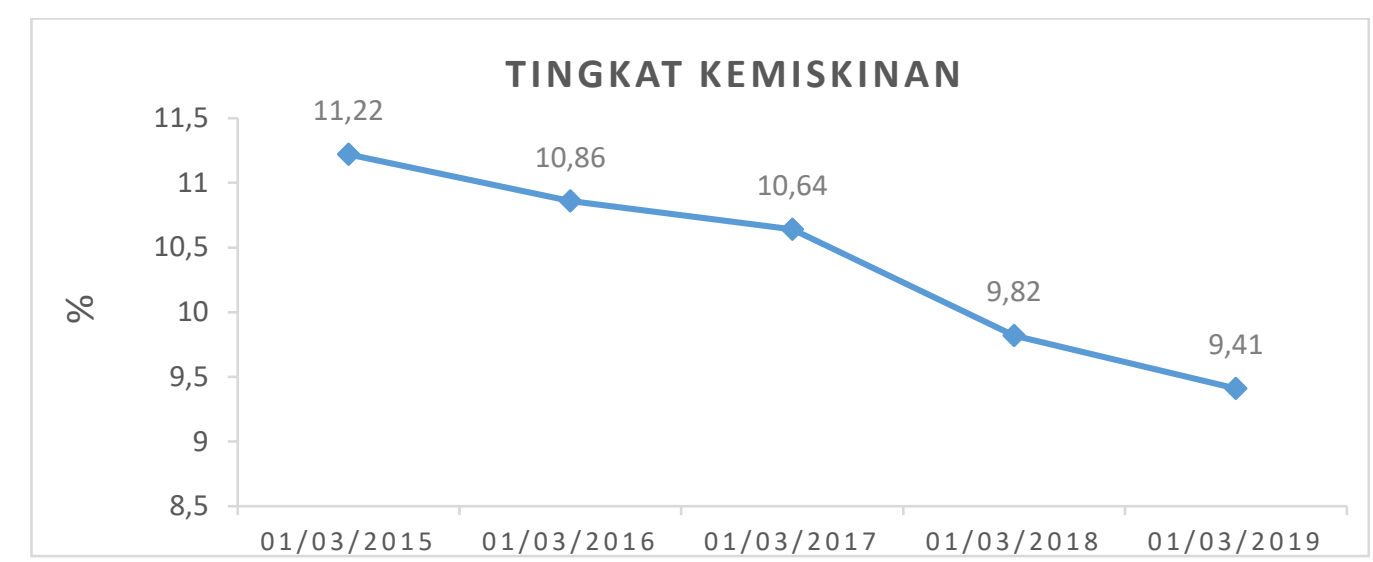

Sumber: Badan Pusat Statistik, diolah

Tingkat kemiskinan di Indonesia periode tahun 2015-2019 mengalami penurunan per-tahunnya. Pada tahun 2019 presentase tingkat kemiskinan mencapai 9,41 dan mengalami penurunan sebesar 0,41 terhadap 2018 dan sebesar 1,23 terhadap Maret 2017.

Upaya menurunkan tingkat kemiskinan dan pengangguran tidak dapat dipisahkan karena saling terkait. Seseorang dikatakan menganggur jika tidak memiliki pendapatan sehingga tidak dapat memenuhi kebutuhan hidupnya dan memicu munculnya kemiskinan.

\section{Kerangka Teori}

\subsection{Kemiskinan}

Menurut World Bank, kemiskinan didefinisikan dengan : "The denial of choice and opportunities most basic for human development to lead a long healthy, creative life and enjoy a decent standard of living freedom, self esteem and the respect of other". Dari definisi tersebut diartikan bahwa kemiskinan adalah suatu kondisi seseorang tidak dapat menentukan pilihan dan kesempatan sebagai kebutuhan dasar manusia meliputi kesehatan, standar hidup layak, kebebasan, harga diri, dan rasa dihormati seperti orang lain. Pengertian kemiskinan dalam cakupan yang lebih luas adalah keterbatasan manusia yang dapat menyebabkan ketidakanyamanan dalam kehidupan, terancamnya penegakan keadilan, terancamnya posisi tawar (bargaining) dalam pergaulan dunia, hilangnya generasi, serta suramnya masa depan bangsa dan negara (Saputra, 2011; Lestari, 2017).

Kemiskinan merupakan masalah yang dihadapi oleh hampir negara di dunia, tidak terkecuali Indonesia. Hal ini dikarenakan kemiskinan itu bersifat multidimensional yang terdiri dari dua aspek yakni aspek primer, berupa miskin akan asset, organisasi sosial politik, pengetahuan, dan keterampilan serta aspek sekunder, berupa miskin akan jaringan sosial, sumber-sumber keuangan, dan informasi. Kemiskinan terwujud dengan bentuk kekurangan gizi, air, perumahan yang sehat, perawatan kesehatan yang kurang baik, dan tingkat Pendidikan yang rendah (Saputra, 2011; Lestari, 2017). Menurut Sumitro Djojohadikusumo (1955) pola kemiskinan terdiri 4 macam, yaitu persistent poverty adalah kemiskinan 
yang turun-temurun, cyclical poverty yaitu kemiskinan yang mengikuti pola siklus ekonomi, seasonal poverty yaitu kemiskinan musiman, dan terakhir accidental poverty, yaitu kemiskinan yang terjadi akibat bencana alam atau dampak dari suatu kebijakan tertentu.

Secara konsep kemiskinan dibagi menjadi dua jenis yaitu kemiskinan absolut dan kemiskinan relatif. Pertama, kemsikinan absolut yaitu kemiskinan yang dihitung berdasarkan standar minimun kebutuhan, WHO menyebutkan sebanyak 10 persen populasi di dunia masuk dalam kategori miskin yakni memiliki pendapatan kurang dari 1,9 dolar per hari. Kedua, kemiskinan relatif yaitu melihat kemiskinan individu atau masyarakat tertentu relatif dengan seluruh masyarakat yang ada (Ningrum, 2019).

Menurut Kuncoro menjelaskan penyebab kemiskinan yang beradasarkan pada teori Nurkse yaitu teori lingkaran kemiskinan (Vicious circle of poverty) dimana terdapat penyebab utama yaitu:

1) Adanya keterbelakangan, dan ketertinggalan Sumber Daya Manusia (SDM), yang tercerminkan dari rendahnya Indeks Pembangunan Manusia (IPM).

2) Ketidaksempurnaan pasar.

3) Kurangnya modal yang menyebabkan rendahnya produktifitas.

Rendahnya produktifitas mencerminkan rendahnya pendapatan yang dihasilkan. Rendahnya pendapatan akan berimplikasi pada tingginya angka kemiskinan.

2.2 Kemiskinan dalam Perspektif Islam

Islam melarang umatnya untuk tidak meninggalkan keluarganya dalam keadaan lemah dan miskin seperti firman Allah dalam QS. An Nisa' sebagai berikut:

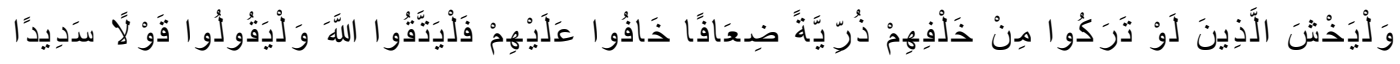

"Dan hendaklah takut kepada Allah orang-orang yang seandainya meninggalkan dibelakang mereka anak-anak yang lemah, yang mereka khawatir terhadap (kesejahteraan) mereka. Oleh sebab itu hendaklah mereka bertakwa kepada Allah dan hendaklah mereka mengucapkan perkataan yang benar." (QS. An Nisa' : 9)

Konsep kemiskinan dalam perspektif islam memiliki perbedaan dengan konvensional. Islam mendefinisikan kemiskinan kedalam dua kategori yaitu fakir dan miskin. Definisi fakir menurut mazhab Syafii dan Hambali yaitu orang yang tidak memiliki penghasilan sama sekali karena ada sebab khusus yang syar'i (uzur syar'i), seperti usia tua, serta sibuk dalam dakwah sehingga tidak sempat untuk mencari nafkah (Lestari, 2017). Yang tercantum pada QS. Al Baqarah (273) :

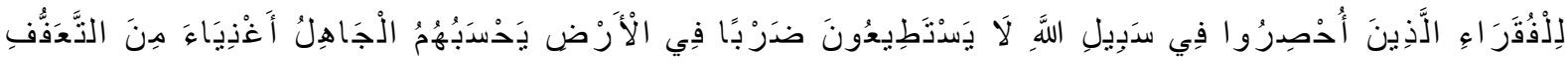

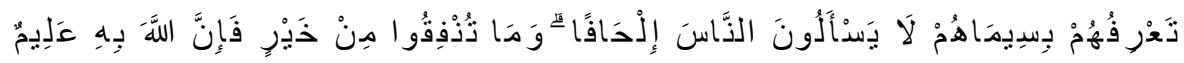

“(Berinfaqlah) kepada orang-orang fakir yang terikat (oleh jihad) di jalan Allah; mereka tidak dapat (berusaha) di bumi; orang yang tidak tahu menyangka mereka orang kaya karena memelihara diri dari minta-minta. Kamu kenal mereka dengan melihat sifat-sifatnya, mereka tidak meminta kepada orang secara mendesak. Dan apa saja harta yang baik yang kamu nafkahkan (di jalan Allah), maka sesungguhnya Allah Maha Mengatahui." (QS. Al Baqarah : 273)

Sedangkan pengertian orang miskin menurut mazhab Syafii dan Hambali adalah orang yang tidak mampu memenuhi kebutuhan diri sendiri dan keluarga meskipun telah memiliki pekerjaan dan penghasilan (Syauqi dalam Lestari).

\subsection{Pengangguran}

Tingkat pengangguran merupakan salah satu aspek untuk menilai kinerja perekonomian (Herlambang, 2001; Lestari, 2017). Pengangguran adalah suatu keadaan seseorang yang termasuk dalam Angkatan kerja tetapi tidak memiliki pekerjaan, atau sedang mencari kerja dan belum mendapatkannya, dan atau secara aktif tidak sedang mencari kerja. BPS (Badan Pusat Statistik) menambahkan pengertian 
pengangguran yaitu seseorang yang bekerja kurang dari dua hari selama seminggu. Menurut Sadono Sukirno (2000) pengangguran dibedakan menjadi 3 jenis berdasarkan penyebabnya, yaitu:

1) Pengangguran friksional, yaitu penganguran yang disebabkan oleh tindakan seseorang pekerja untuk meninggalkan kerjanya dan mencari kerja yang lebih baik atau sesuai dengan keinginannya.

2) Pengangguran struktural, yaitu pengangguran yang disebabkan oleh adanya perubahan struktur dalam perekonomian.

3) Pengangguran konjungtur, yaitu pengangguran yang disebabkan oleh kelebihan pengangguran alamiah dan berlaku sebagai akibat pengurangan dalam permintaan agregat.

Pengangguran beradasarkan cirinya terdiri dari 4 jenis, yaitu:

1) Pengangguran Terbuka (Open Unemployment), yaitu keadaan tenaga kerja yang tidak memiliki pekerjaan atau tidak bekerja sama sekali. Hal ini karena tidak adanya lapangan pekerjaan atau lapangan pekerjaan tidak sesuai dengan harapan.

2) Pengangguran Tersembunyi (Disguised Unemployment), yaitu tenaga kerja yang bekerja tidak sesuai dengan keahliannya.

3) Pengangguran Bermusim, yaitu pengangguran yang disebabkan adanya perubahan musim atau terjadinya perubahan permintaan tenaga kerja secara berkala.

4) Setengah Menganggur (Under Unemployment), yaitu tenaga kerja yang jam kerjanya dibawah jam kerja normal atau kurang dari 35-40 jam per minggunya.

Berikut disajikan Tingkat Pengangguran Terbuka Seluruh Provinsi di Indonesia pada tahun 2019 adalah sebagai berikut:

\section{Gambar 2}

Tingkat Pengangguran Terbuka Seluruh Provinsi di Indonesia Tahun 2019

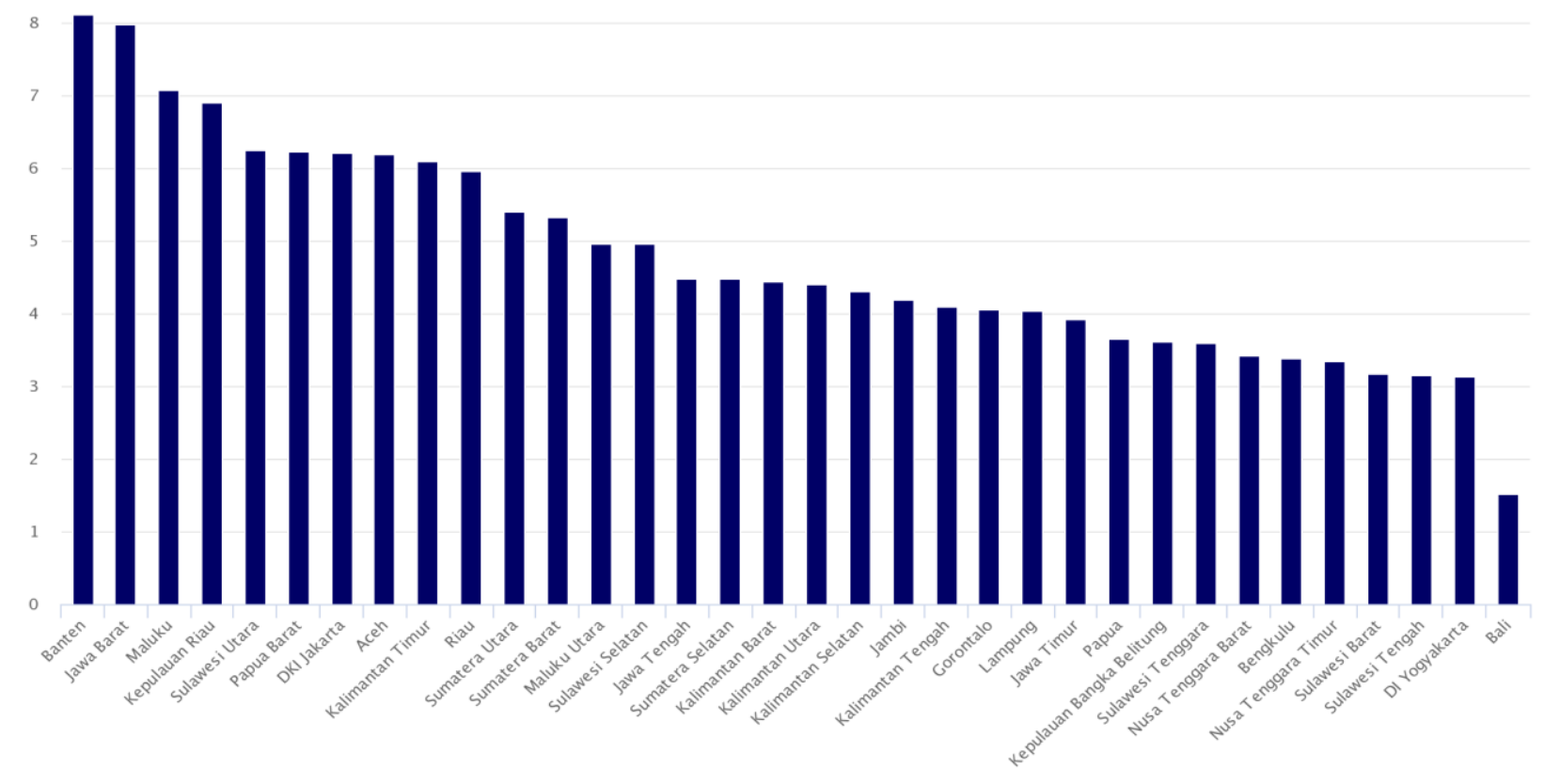

SDGs Dashboard, http://sdgs.bappenas.go.id/dashboard/

Sumber : Bappenas, 2019 
Sedangkan menurut Tambunan, 2001 pengangguran dapat mempengaruhi tingkat kemiskinan dengan berbagai cara, antara lain:

1. Jika rumah tangga memiliki batasan likuiditas yang berarti bahwa konsumsi saat ini sangat dipengaruhi oleh pendapatan saat ini, maka bencana pengangguran akan secara langsung mempengaruhi income poverty rate dengan consumption poverty rate.

2. Jika rumah tangga tidak menghadapi batasan likuiditas yang berarti bahwa konsumsi saat ini tidak terlalu dipengaruhi oleh pendapatan saat ini, maka peningkatan pengangguran akan menyebabkan peningkatan kemiskinan dalam jangka panjang, tetapi tidak terlalu berpengaruh dalam jangka pendek.

\section{Hasil dan Pembahasan}

Salah satu Tujuan Pembangunan Berkelanjutan (TPB) atau Sustainable Development Goals (SDGs) yaitu menjaga kesejahteraan ekonomi masyarakat. TPB atau SDGs ini merupakan komitmen global dan nasional dalam upaya menjaga kesejahteraan masyarakat yang salah satunya mencakup tujuan yaitu, tanpa kemiskinan (Bappenas). Di Indonesia upaya penanggulangan kemiskinan menjadi prioritas nasional pada setiap rencana kerja pemerintah setidaknya dalam 4 periode Rencana Pembangunan Jangka Menengah.

Indonesia telah berhasil menurunkan tingkat kemiskinan sebesar 1 digit, yakni pada tahun 2019 persentase tingkat kemiskinan mencapai 9,41 dan mengalami penurunan sebesar 0,41 terhadap 2018 dan sebesar 1,23 terhadap Maret 2017. Namun, dibeberapa provinsi angka kemiskinan masih cenderung tinggi, melalui penelitian yang berjudul "Analisis Wilayah dengan Kemiskinan Tinggi" oleh Kementerian PPN/Bappenas pada tahun 2018 setidaknya terdapat provinsi yang memiliki angka kemiskinan diatas 15 persen seperti di Provinsi Papua (27,74 persen), Papua Barat (23,01 persen), Nusa Tenggara Timur/NTT (21,35 persen), Maluku (18,12 persen), Gorontalo (16,81 persen), Aceh (15,97 persen) dan Bengkulu (15,43 persen). Oleh karena itu diambil 3 provinsi untuk mewakili penelitian tersebut yaitu provinsi NTT, Papua, dan Maluku. Kemudian terdapat beberapa aspek yang dinilai salah satunya adalah aspek ketenagakerjaan. Provinsi NTT, Papua, dan Maluku tergolong pada Kawasan Timur Indonesia (KTI) yang angka kemiskinannya relatif lebih tinggi jika dibandingkan dengan Kawasan Barat Indonesia (KBI).

Berikut disajikan Proporsi Penduduk Bekerja menurut Lapangan Pekerjaan Utama di wilayah KTI tahun 2017 adalah sebagai berikut:

\section{Gambar 3 \\ Penduduk Bekerja menurut Lapangan Pekerjaan Utama di KTI}

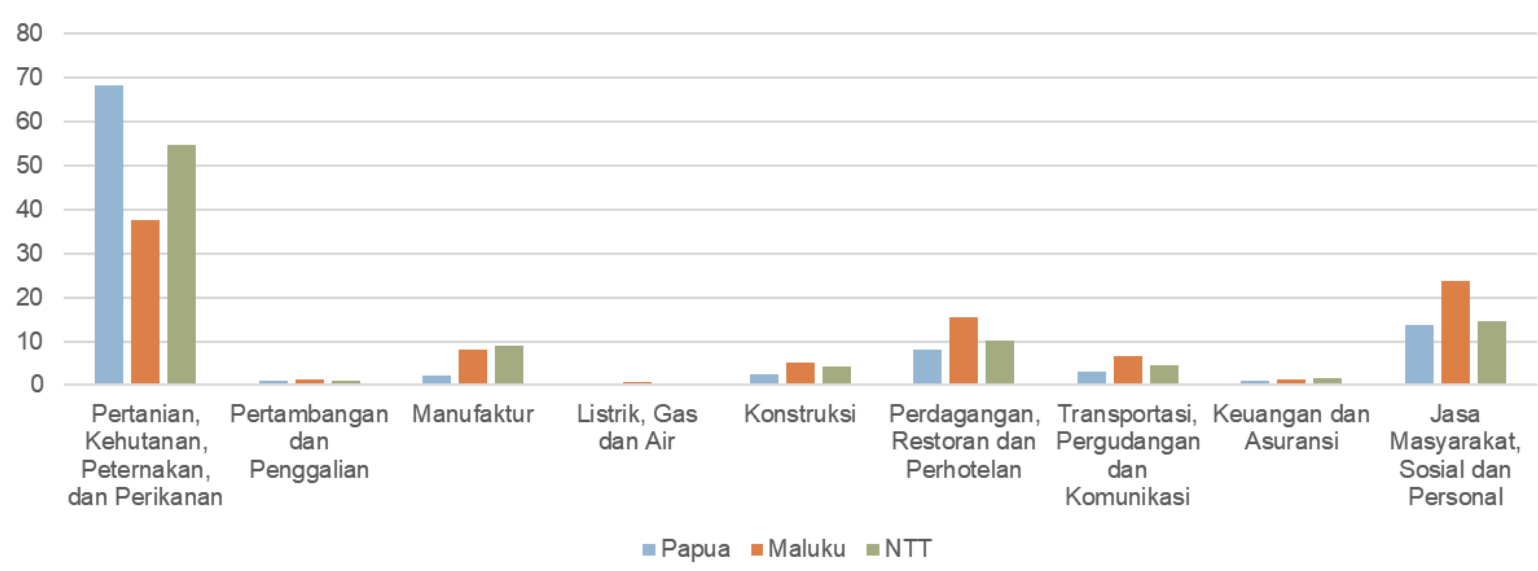

Sumber: BPS, Agustus 2017 (diolah dari SEPAKAT) 
Mayoritas pekerjaan penduduk pada daerah KTI fokus pada sektor pertanian. Sebagian besar kegiatan sektor pertanian masih bersifat tradisonal. Artinya kegiatan pertanian yang dilakukan oleh masyarakat hanya untuk mempertahankan hidup. Bappenas menilai terkait aspek ketenagakerjaan, terdapat beberapa hal penting untuk disoroti seperti jenis pekerjaan menurut lapangan pekerjaan utama, status bekerja dari pekerja (pekerja formal atau informal), tingkat pengangguran terbuka, dan setengah pengangguran, adalah sebagai berikut:

\section{1) Lapangan pekerjaan utama dan status bekerja.}

Berdasarkan data BPS, pada Agustus 2018, sebanyak 35,70 persen penduduk Indonesia usia 15 tahun ke atas bekerja di sektor pertanian, kehutanan, dan perikanan, baik berusaha sendiri maupun sebagai buruh atau karyawan. sisanya bekerja pada kegiatan di sektor lainnya seperti perdagangan, transportasi, konstruksi, dan lain-lainnya. Pada wilayah KTI kegiatan sektor pertanian merupakan lapangan kerja utama bagi sebagian angkatan kerja. Di Provinsi NTT misalnya pada tahun 2017 sebesar 54,81 persen angkatan kerja yang bekerja di sektor pertanian, disusul 65,83 persen di Papua, sedangkan presentase Angkatan kerja secara nasional yang bekerja di sektor pertanian pada Agustus 2017 hanya 39,92 persen.

Berdasarkan status bekerja penduduk usia 15 tahun ke atas, lebih dari 60 persen tenaga kerja KTI bekerja di sektor informal dan mayoritas dari penduduk miskin berada di sektor ini. Pada Agustus 2018, presentase pekerja sektor informal di seluruh provinsi Indonesia adalah sebagai berikut :

Berikut disajikan presentase Desa menurut Lapangan Pekerjaan Mayoritas Penduduknya tahun 2018 adalah sebagai berikut:

\section{Gambar 4 \\ Persentase Desa menurut Lapangan Pekerjaan Mayoritas Penduduknya, 2018}

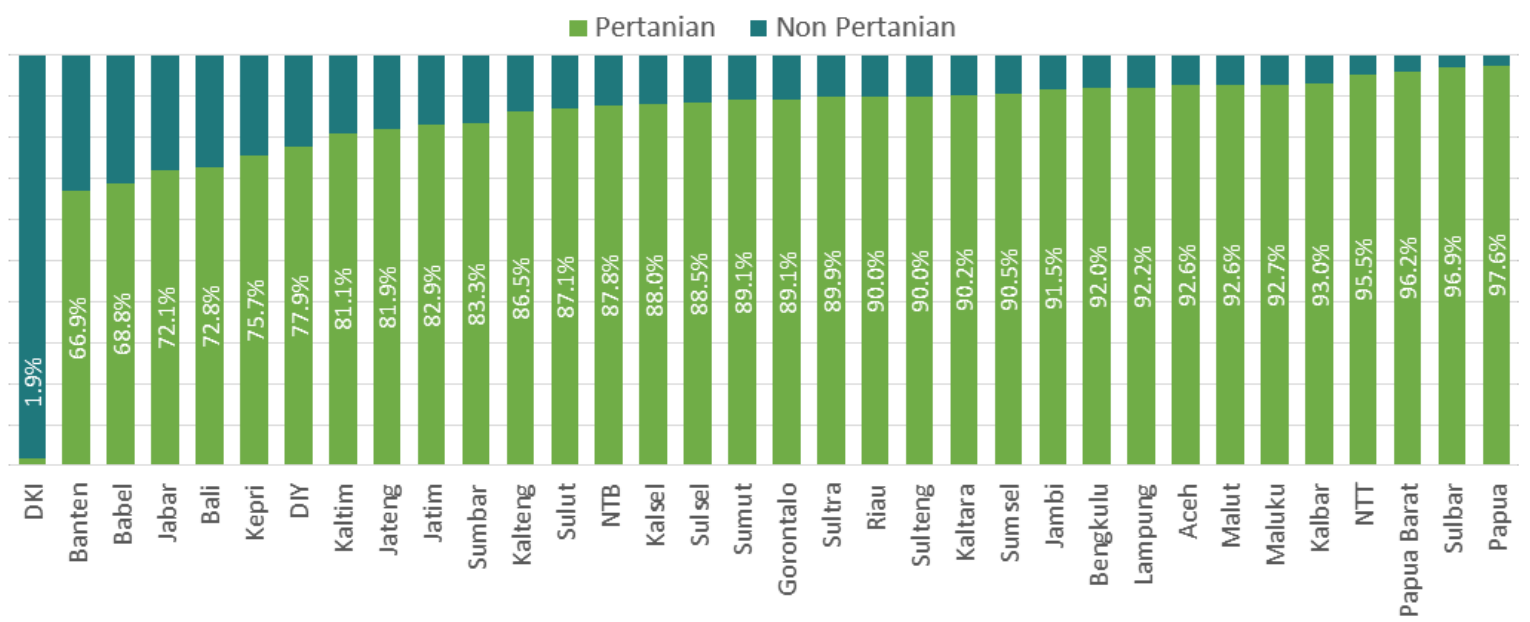

Komoditi utama sektor pertanian yang diproduksi sebagian besar penduduk desa di provinsi:

Papua: palawija, perikanan, hortikultura

Sulbar: padi, kakao, kelapa sawit

Papua Barat: palawija, hortikultura, perikanan

NTT: palawija, padi, kelapa

Kalbar: karet, padi, kelapa sawit

Sumber; Badan Pusat Statistik,2018

Pertanian yang menjadi sektor utama masyarakat desa menadapatkan penghasilan tidak serta merta terbebas dari kemiskinan. Penyebabnya adalah jumlah lahan garapan yang kecil, dengan lahan bertani yang kecil berimbas pada jam kerja yang sedikit tetapi dengan melibatkan tenaga kerja yang 
banyak. maka tidak heran walaupun tidak menganggur tetapi menyebabkan petani tetap dalam kemiskinan (Yacoub, 2012).

2) Tingkat Pengangguran Terbuka (TPT) dan Setengah Pengangguran.

Tingkat Pengangguran Terbuka pada provinsi-provinsi KTI sebesar 4,31 persen dari 5,34 persen TPT nasional. Kemudian Provinsi KTI memiliki setengah pengangguran lebih tinggi dibandingkan dengan rata-rata nasional. Bahkan dibeberapa provinsi dengan tingkat kemiskinan tinggi cenderung memiliki tingkat setengah pengangguran yang tinggi. Sebagai contoh Provinsi NTB pada tahun 2017 tingkat setengah penganggurannya adalah 17,27 persen, disusul NTT (12,90 persen), Maluku (12,30 persen), Papua Barat (12,27 persen), Sulawesi Barat (11,71 persen), Sulawesi Tengah (11,64 persen), dan Sulawesi Tenggara (10,76 persen). Selanjutnya secara nasional pada tahun 2017 tingkat pengangguran sebesar 5,5 persen dengan persentase jumlah penduduk miskin sebesar 10,12 persen.

Berikut disajikan persentase Jumlah Penduduk Miskin dan pengangguran di Indonesia dalam periode 2015-2018 adalah sebagai berikut:

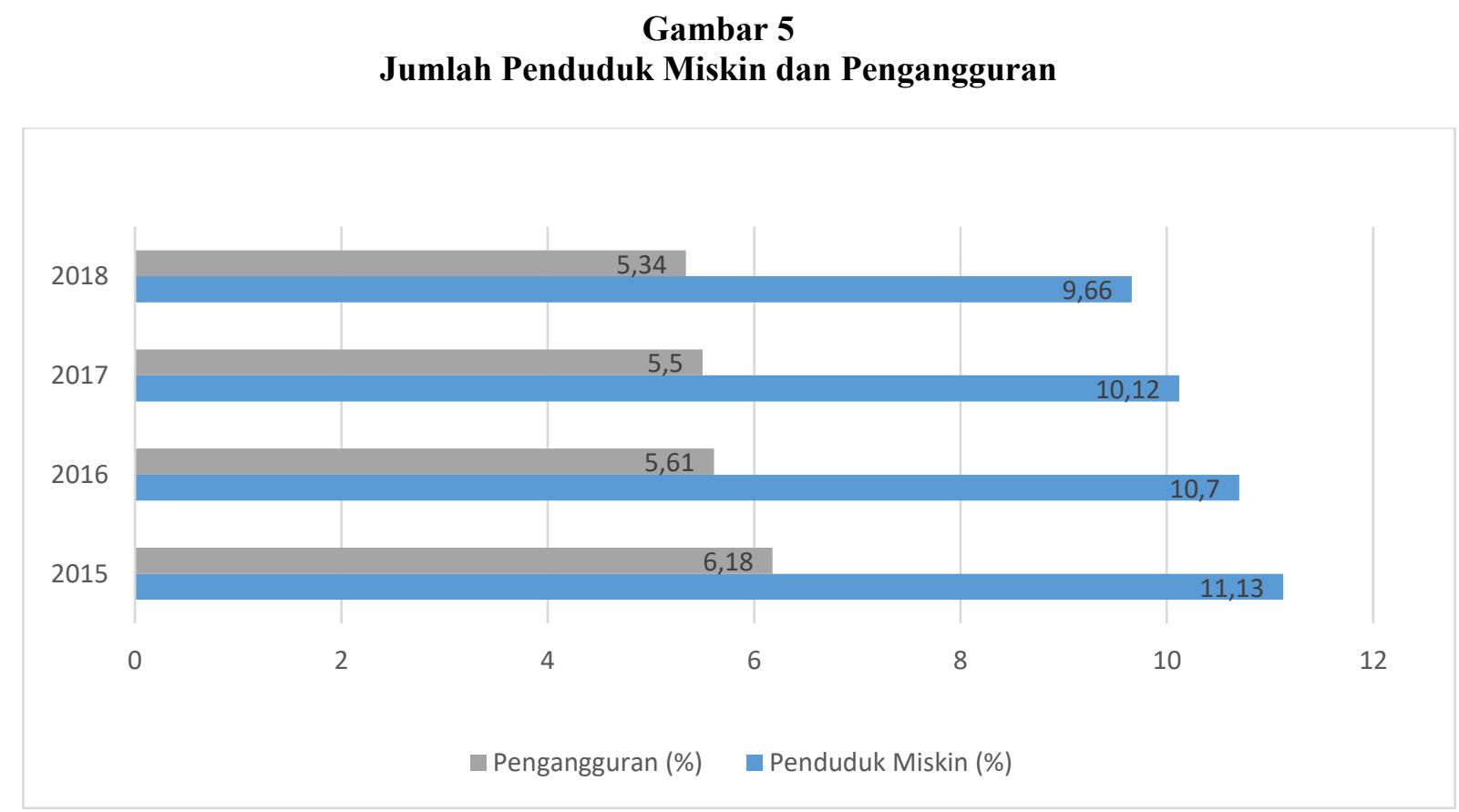

Sumber: Badan Pusat Statistik, diolah

Terdapat korelasi yang kuat antara tingkat pengangguran terutama tingkat setengah pengangguran yang tinggi dengan tingkat kemiskinan yang tinggi (Bappenas, 2018).

Menurut Chapra, islam menjadi agama keseimbangan, telah memberikan penekanan yang sama apada kedua spiritual dan duniawi (Lestari, 2017). Islam sangat menganjurkan umatnya untuk bekerja, kerja ('amal) adalah segala aktivitas badaniah maupun rohaniah yang bertujuan untuk menambah manfaat yang dibolehkan dalam syariat islam.

Dalam islam kemiskinan disebabkan oleh beberapa faktor, yaitu:

1. Faktor Individu, mecakup:
a. Faktor kemalasan
b. Faktor cacat atau uzur
c. Faktor rendahnya Pendidikan dan keterampilan

2. Faktor sistem sosial
a. Ketimpangan antara jumlah tenaga kerja dengan lapangan pekerjaan
b. Kebijakan pemerintah yang tidak pro-rakyat
c. Banyaknya tenaga kerja sebagai akibat pertumbuhan penduduk (Naf'an; Marlena) 
Penyebab kemiskinan dalam perspektif ekonomi Syariah, yakni berasal dari faktor sistem sosial, yang diakibatkan tidak seimbangnya jumlah tenaga kerja dengan lapangan pekerjaaan atau disebut dengan pengangguran. Islam sangat mencela pengangguran yaitu orang yang tidak mau bekerja dengan alasan kemalasan, gaji yang sedikit, serta pekerjaan yang tidak memadai ( Yunus; Marlena). Seperti dalam Firman Allah SWT yang berbunyi:

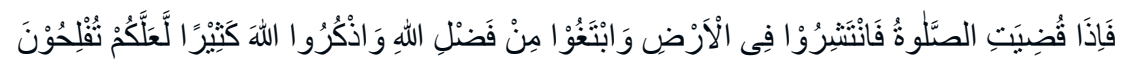

Artinya : Apabila telah ditunaikan shalat, Maka bertebaranlah kamu dimuka bumi; dan carilah karunia Allah dan ingatlah Allah banyak-banyak supaya kamu beruntung”. (Qs. Al-Jumuah [62] : 10)

Dalam ayat tersebut menunjukan bahwa perintah bekerja mencari rezeki dalam rangka memperoleh keberuntungan dilaksanakan apabila telah ditunaikannya perkara ibadah,

Model CIBEST (Syauqi, 2016) menjelaskan indeks kemiskinan materiil, indeks kesejahteraan, indeks kemiskinan spiritual dan indeks kemiskinan absolut Kuadran CIBEST membagi kemampuan rumah tangga dalam memenuhi kebutuhan material dan spiritual kedalam dua tanda yaitu tanda positif $(+)$ dan negative (-). Tanda (+) berarti rumah tangga mampu memenuhi kebutuhannya dan tanda (-) jika rumah tangga tidak mampu memenuhi kebutuhannya.

Melalui Model CIBEST mampu mendesain program pengentasan kemiskinan yang tidak hanya terfokus peningkatan pendapatan saja melainkan diperkuat aspek spiritual serta mampu melahirkan individu kuat sisi spiritulanya, yang sekurang-kurangnya didasarkan pada tiga karakter utama. Yaitu, memiliki ketaatan kepada Allah, memiliki semangat berbagi dan kepedulian yang kuat, dan sangat memperhatikan kondisi keutuhan keluarga dan lingkungan, sehingga potensi kebaikan yang ada pada dirinya bisa terus dikembangkan (BAZNAS, 2020).

\section{Kesimpulan}

Kemiskinan merupakan masalah multidimensi sehingga tidak hanya dengan satu variable saja, yaitu pengaruh kemiskinan terhadap pengagguran tetapi terdapat variable-variabel lain yang mempengaruhinya contoh tingkat inflasi, pertumbuhan ekonomi, pembangunan nasional, dan lain-lain. Pengangguran terbuka menjadi faktor utama tingginya kemiskinan di Indonesia. Semakin banyak penganguran maka jumlah penduduk miskin juga akan semakin meningkat. Dalam kondisi negara agraris yang tentunya erat dengan pertanian, tidak serta merta membuat penduduk dengan kegiatan bertani terlepas dari kemiskinan. Pendapatan yang kecil sehingga tidak mampu memenuhi kebutuhan hidup menjadi andil utama mereka tetap miskin, pun tidak menganggur. Islam tidak hanya mendefinisikan miskin dari sisi materiil namun juga sisi spiritual. Dalam perspektif ekonomi Syariah, pengangguran merupakan penyebab kemiskinan, semakin tinggi pengangguran maka peluang individu tidak dapat memenuhi kebutuhannya semakin besar, sehingga semakin banyak penduduk yang menganggur maka semakin banyak juga penduduk yang berada dalam garis kemiskinan.

\section{Daftar Pustaka}

https://www.bps.go.id/

$\underline{\text { http://sdgs.bappenas.go.id/ }}$

https://litequran.net/

Beik, I. S., Memperkuat Riset Ekonomi Islam, 2020. Website: https://baznas.go.id/pendistribusian/kolom/direktur-pp/1492-memperkuat-riset-ekonomi-islam

Beik, I. S. (2020). Memperkuat Riset Ekonomi Islam. Website:

Kalsum, Umi., (-). Pengaruh Pengangguran dan Inflasi Pertumbuhan Ekonomi di Sumatera Utara. Kementerian PPN/Bappenas., 2018. Analisis Wilayah dengan Kemiskinan Tertinggi. 
Lestari, R. P., 2017. Analisis Pengaruh Indeks Pembangunan Manusia, Pengangguran, dan Produk Domestik Regional Bruto terhadap Tingkat Kemiskinan di Provinsi Lampung dalam Perspektif Ekonomi Islam Tahun 2011-2015. Skripsi, Fakultas Ekonomi dan Bisnis Islam, Universitas Islam Raden Intan Lampung.

Marlena, D., 2019. Lestari, R. P., 2017. Analisis Pengaruh Pengangguran Terbuka dan Tingkat Pendidikan terhadap Jumlah Penduduk Miskin dalam Perspektif Ekonomi Islam di KotaBumi Kabupaten Lampung Utara Tahun 2009-2018. Skripsi, Fakultas Ekonomi dan Bisnis Islam, Universitas Islam Raden Intan Lampung.

Ningrum, Vanda., 2018. Pusat Penelitian Kependudukan LIPI. Website: https://kependudukan.lipi.go.id/id/kajian-kependudukan/kemiskinan/681-kemiskinan-dalamperspektif -global-nasional-dan-lokal\#top

Sukirno, Sadono., 2004. Makroekonomi Teori Pengantar. Edisi Ketiga. Jakarta, Grafindo, Persada. Tambunan, Tulus., 2001. Perekonomian Indonesia: Teori dan Temuan Empiris, Jakarta: Ghalia. World Bank., 1990. World development Report: Poverty, New York: Oxfprd University Press.

Yacoub, Yarlina., 2012. Pengaruh Tingkat Pengangguran terhadap Tingkat Kemiskinan Kabupaten/Kota di Provinsi Kalimantan Barat. ISSN 1693-9093 8(3), 176-185. 